\title{
Analisis Faktor-Faktor yang Mempengaruhi Perilaku Brand Switching pada Kartu Prabayar \\ XL (Studi pada konsumen Pandumedia Reload Service Singosari-Malang) \\ Nuraeni
}

Dosen Program Studi Ilmu Administrasi Niaga

\begin{abstract}
ABSTRAK
Tujuan penelitian ini ada 3 yaitu 1) untuk mengetahui apakah variabel iklan, kebutuhan mencari variasi (variety seeking), harga, tingkat keterlibatan dan kepuasan berpengaruh secara parsial dan simultan terhadap keputusan perpindahan merek (brand switching).2) untuk mengetahui seberapa besar pengaruh iklan, kebutuhan mencari variasi (variety seeking), harga, tingkat keterlibatan dan kepuasan terhadap keputusan perpindahan merek (brang switching), dan 3) untuk mengetahui variabel mana antara iklan, kebutuhan mencari variasi (variety seeking), harga, tingkat keterlibatan dan kepuasan yang paling besar pengaruhnya terhadap keputusan perpindahan merek (brand switching).

Jenis penelitian yang digunakan adalah penelitian assosiatif (hubungan). Penelitian ini dilakukan pada konsumen Pandumedia Reload Service yang bertempat di Jalan Raya no.88 Singosari Malang. Pandumedia Reload Service adalah salah satu usaha yang bergerak di bidang penjualan pulsa elektrik all operator yang juga merupakan distributor pulsa elektrik. Teknik pengambilan sampel yang digunakan adalah teknik sampling purposive. Jadi sampel yang diambil ditentukan oleh peneliti dengan memberikan karakteristik sebagai pertimbangan dengan jumlah 100 orang.

Hasil analisa menunjukkan bahwa kelima variabel independen (iklan, variety seeking, harga, tingkat keterlibatan dan kepuasan) secara simultan berpengaruh terhadap keputusan perpindahan merek pada kartu prabayar XL. Ini dibuktikan dengan nilai $f_{\text {hitung }}(11.615)>f_{\text {tabel }}(2.311)$ dengan nilai signifikan $<0.05$ yaitu 0.000 . Hal ini menunjukkan bahwa hipotesis pertama yang menduga terdapat pengaruh secara simultan antara variabel iklan $\left(\mathrm{X}_{1}\right)$, variety seeking $\left(\mathrm{X}_{2}\right)$, harga $\left(\mathrm{X}_{3}\right)$, tingkat keterlibatan $\left(\mathrm{X}_{4}\right)$ dan kepuasan $\left(\mathrm{X}_{5}\right)$ terhadap keputusan perpindahan merek (brand switching) diterima.
\end{abstract}

\section{PENDAHULUAN}

\section{Latar Belakang}

Beragamnya produk atau jasa yang beredar pesat di pasaran merupakan salah satu bukti bahwa telah terjadi persaingan yang semakin ketat di bidang bisnis. Para pemegang usahapun kini dituntut untuk lebih kreatif dan inovatif dalam memproduksi dan memasarkan produknya agar bisa laku di pasaran dan dapat bersaing dengan perusahaan lain. Salah satu bidang usaha yang terlihat mengalami persaingan ketat adalah usaha pertelekomunikasian.
Salah satu jenis sarana telekomunikasi yang banyak dipilih masyarakat dengan alasan praktis dan mudah dibawa kemana saja adalah telepon seluler (handphone). Selain itu, akibat kemajuan teknologi yang menuntut perusahaan telepon seluler untuk terus meningkatkan dan mengembangkan produk mereka telah membuat konsumen semakin tergiur untuk memiliki produk tersebut. Kini telepon seluler tak hanya berfungsi sebagai alat telekomunikasi. Beraneka ragam fasilitas seperti MP3, video, kamera, game, radio, bluetooth, TV dan internet kini telah tersedia di dalam telepon seluler.

Berbicara mengenai telepon seluler maka tak lepas dari operator seluler sebagai penyedia 
jasa dari telepon seluler. Jasa dari operator seluler sendiri bisa didapat jika menggunakan produk dari operator seluler tersebut yaitu kartu seluler. Industri kartu seluler di Indonesia diawali dengan dua operator seluler berbasis GSM (Global System for Mobile Communication) yaitu PT Telekomunikasi Seluler dan PT Indosat Tbk. Beberapa tahun kemudian bermunculan berbagai macam operator seluler lain yang ikut meramaikan industri seluler GSM di Indonesia.

Sejalan dengan semakin banyaknya produk kartu seluler di pasaran, fasilitas yang ditawarkan semakin beragam pula. Jasa layanan yang disediakan kini tidak hanya untuk telepon dan sms saja, namun layanan lainnya seperti MMS dan fitur-fitur dari internet juga telah tersedia di dalam kartu seluler. Maka tak dapat dipungkiri bahwa beragamnya merek kartu seluler dengan pilihan fasilitas yang menarik menimbulkan persaingan di bidang bisnis tersebut kian ketat.

Persaingan ini bisa menguntungkan juga bisa merugikan. Menguntungkan di sisi konsumen karena ketika perusahaan operator seluler saling berlomba untuk menawarkan produknya, konsumen dapat memilih berbagai pilihan merek sesuai yang dikehendakinya. Hal tersebut tentunya dapat mengakibatkan konsumen berganti operator seluler setiap saat. Dengan terjadinya pergantian opeartor seluler maka dengan pasti konsumen melakukan perpindahan merek (brand switching). "Perpindahan merek (brand switching) adalah perpindaham loyalitas dari satu merek ke merek lain dalam kategori produk sejenis untuk berbagai macam alasan tertentu" (Petter dan Olson: 2003).

Salah satu operator seluler yang ada di Indonesia yaitu XL dengan produknya XL prabayar. PT XL Axiata Tbk atau yang biasa disebut XL adalah sebuah perusahaan operator telekomunikasi seluler terkemuka di Indonesia yang mulai beroperasi secara komersial pada tanggal 8 Oktober 1996 dan merupakan perusahaan swasta pertama yang menyediakan layanan telepon seluler di Indonesia (www.xl.co.id). Bebagai macam program menarik telah dikeluarkan oleh kartu prabayar $\mathrm{XL}$, salah satunya yaitu dari XL bebasnya yang memberikan layanan gratis internet. Selain itu paket hemat dan paket super hemat telepon dan sms yang begitu murah juga telah dikeluarkan oleh XL. Semua ini dilakukan oleh XL tidak lain adalah untuk mempertahankan pelanggan mereka agar tidak beralih ke operator lain.

Ada beberapa faktor yang menyebabkan seorang konsumen melakukan perpindahan merek (brand switching), salah satunya yaitu karena adanya iklan. Hal ini sesuai dengan yang dikatakan Shimp (2003) "Periklanan lebih jauh dapat digunakan untuk mempengaruhi peralihan merek (brand switching)". Pemikiran ini juga diperkuat dengan hasil penelitian yang dilakukan Radamuri dkk, (2013) bahwa faktor iklan berpengaruh terhadap perilaku brand switching.

Perpindahan merek (brand switching) juga dapat muncul karena variety seeking. Tjiptono (2008) mengidentifikasi sejumlah motif pelanggan untuk beralih merek. Motifmotif tersebut dikelompokkan menjadi motif 
intenal dan eksternal. Motif internal mencerminkan true variety seeking, merupakan perilaku beralih merek yang dilakukan demi mencari variasi semata dan disebabkan faktor intrinsik seperti rasa ingin tahu, kebutuhan akan perubahan untuk mengatasi kebosanan terhadap suatu merek, atau menghindari kejenuhan atribut tertentu. Motif eksternal mereflesikan derived varied behaviour yang dipicu oleh nilai fungsional atau instrumental merek atau produk alternatif dan faktor eksternal lainnya seperti yang terkait dengan waktu, uang, manfaat, ataupun resiko kinerja yang melekat dengan tindakan mereka dalam peralihan merek.

Harga juga menjadi salah satu faktor yang menyebabkan seorang konsumen melakukan perpindahan merek (brand switching). Cahyono dan Soesanto (2012) dalam penelitiannya pada produk rokok Sampoerna mengatakan, "Harga produk rokok Sampoerna yang lebih mahal dari rokok wajah merek lain atau harganya sesuai dengan manfaat dari rokok Sampoerna akan mengakibatkan konsumen berpindah ke merek rokok lain". Hal ini sesuai dengan yang dikatakan Swastha (2003) "Harga suatu merek yang terlalu mahal dengan karakteristik yang ditawarkan sama dengan merek pesaing dapat menyebabkan konsumen berpindah merek, konsumen akan loyal pada merek yang berkualitas dengan harga yang wajar".

Faktor lain yang menyebabkan konsumen melakukan perpindahan merek adalah tingkat keterlibatan. Menurut Swastha (2003) "Perpindahan merek dilakukan oleh konsumen terjadi pada produk-produk dengan karakteristik keterlibatan pembelian yang rendah". Hal ini dikuatkan dengan penelitian yang dilakukan Pranita dan Irawanto (2011) bahwa para responden cukup menggunakan ketelibatannya di dalam memilih kartu seluler yang digunakannya. Keterlibatan dapat berkisar dari tingkat rendah (sedikit atau tidak ada relevansi) ke moderat (ada relevansi yang dirasakan) hingga ke tingkat tinggi (relevansinya sangat dirasakan).

Selain faktor-faktor yang telah disebutkan di atas, faktor kepuasan juga berpengaruh terhadap perilaku perpindahan merek (brand switching). Menurut Kotler \& Keller (2009) "Kepuasan pelanggan adalah perasaan senang atau kecewa seseorang yang muncul setelah membandingkan antara persepsi atau kesannya terhadap kinerja atau hasil suatu produk dan jasa serta kesesuaian dengan harapannya. Jika kinerja produk lebih buruk dari harapan konsumen, maka konsumen akan mengalami ketidakpuasan. Seorang konsumen yang mengalami ketidakpuasan pada masa pasca konsumsi mempunyai kemungkinan akan merubah perilaku keputusan belinya dengan mencari alternatif merek lain pada konsumsi berikutnya untuk meningkatkan kepuasannya". Emelia (2010), Koencoro dan Marlien (2009) dalam penelitian mereka menyimpulkan bahwa apabila kepuasan semakin tinggi maka brand switching semakin menurun.

\section{Tujuan Penelitian}

1. Untuk mengetahui apakah variabel iklan, kebutuhan mencari variasi (variety seeking), harga, tingkat keterlibatan dan kepuasan berpengaruh 
secara parsial dan simultan terhadap keputusan perpindahan merek (brand switching).

2. Untuk mengetahui seberapa besar pengaruh iklan, kebutuhan mencari variasi (variety seeking), harga, tingkat keterlibatan dan kepuasan terhadap keputusan perpindahan merek (brang switching).

3. Untuk mengetahui variabel mana antara iklan, kebutuhan mencari variasi (variety seeking), harga, tingkat keterlibatan dan kepuasan yang paling besar pengaruhnya terhadap keputusan perpindahan merek (brand switching).

\section{KERANGKA TEORITIS DAN HIPOTESIS}

\section{Merek}

Merek merupakan sebuah tanda agar konsumen dapat membedakan antara satu produk dengan produk lainnya. Sebuah merek juga membantu konsumen untuk mengingat dan mempermudah saat melakukan pembelian suatu produk atau jasa. Namun dengan munculnya berbagai macam merek yang ada di pasaran akan menjadikan konsumen dihadapkan pada berbagai pilihan merek, dan hal inilah yang menyebabkan seorang konsumen melakukan perpindahan merek.

\section{Perpindahan Merek (Brand Switching)}

Beragamnya merek dari suatu produk yang beredar pesat di pasaran telah membuat konsumen dihadapkan pada berbagai pilihan merek. Hal inilah yang menyebabkan konsumen melakukan perpindahan merek (brand switching). Menurut Swastha (2003) "Perilaku perpindahan merek pada pelanggan merupakan fenomena yang kompleks yang dipengaruhi faktor-faktor keperilakuan, persaingan dan waktu".Perpindahan merek (brand switching) adalah perpindahan loyalitas dari satu merek ke merek lain dalam kategori produk sejenis, untuk berbagai macam alasan tertentu" (Petter dan Olson: 2003). Berbicara mengenai perpindahan merek (brand switching), pastinya ada suatu hal atau faktor yang menyebabkan seorang konsumen melakukan perpindahan merek (brand switching). Faktor tersebut diantaranya adalah iklan, kebutuhan mencari variasi (variety seeking), harga, tingkat keterlibatan dan kepuasan.

Iklan

Iklan (adversiting) adalah setiap bentuk komunikasi non personal mengenai suatu organisasi, produk, servis, atau ide yang dibayar oleh sponsor yang diketahui" (Morissan: 2010). Menurut Kotler \& Keller (2009), "Iklan adalah cara yang berbiaya efektif dalam menyampaikan pesan untuk membangun persepsi merek atau untuk mendidik orang. Tjiptono (2008) berpendapat bahwa iklan memiliki tiga tujuan utama yaitu menginformasikan produk yang ditawarkan dan menciptakan permintaan awal, membujuk dan mempengaruhi konsumen untuk membeli produk yang ditawarkan, serta mengingatkan konsumen mengenai keberadaan suatu produk serta berupaya melekatkan nama atau merek produk tertentu di benak konsumen. Selain itu Tjiptono (2008) juga mengklasifikasikan 
tujuan iklan sebagai efek komunikasi, antara lain:

1. Menumbuhkan persepsi pelanggan terhadap suatu kebutuhan (categoryneed).

2. Memperkenalkan dan memberikan pemahaman tentang suatu produk kepada konsumen (brand awareness).

3. Mendorong pemilihan terhadap suatu produk (brand attitude).

4. Membujuk pelanggan untuk membeli suatu produk (brand purchase intention).

5. Menanamkan citra produk dan perusahaan (positioning).

\section{Kebutuhan Mencari Variasi (Variety Seeking)}

Kebutuhan mencari variasi (variety seeking) adalah suatu hal yang dimiliki oleh sebagian konsumen. Mengidentifikasi pelanggan yang suka mencari variasi merupakan salah satu hal yang penting bagi perusahaan karena perilaku perpindahan merek (brand switching) dapat muncul karena adanya kebutuhan mencari variasi (variety seeking). Hal ini sesuai dengan yang dikatakan Kotler \& Keller (2009) bahwa peralihan merek terjadi untuk mencari keragaman dan bukan karena ketidakpuasan.

Berikut terdapat beberapa tipe konsumen yang mencari variasi (variety seeking) menurut Schiffman dan Kanuk (2007):

1. Perilaku Pembelian yang Bersifat Penyelidikan

(Explanatory
Purchase Behavior), merupakan keputusan perpindahan merek untuk mendapatkan pengalaman baru dan kemungkinan alternatif yang lebih baik.

2. Penyelidikan Pengalaman Orang Lain (Vicarious Exploration), yaitu konsumen mencari informasi tentang suatu produk yang baru atau alternatif yang berbeda, kemudian mencoba menggunakannya.

3. Keinovatifan Pemakaian (Use Innovativeness), konsumen telah menggunakan dan mengadopsi suatu produk dengan mencari produk yang lebih baru dengan teknologi yang lebih tinggi seperti produk-produk alat elektronik yang model/ fungsinya telah berubah.

Menurut Petter dan Olson (2003) "Mencari variasi (variety seeking) bisa menguntungkan atau merugikan. Menjadi menguntungkan ketika memberi kesempatan pada produk baru (brand follower) untuk mendapat tempat di hati konsumen ketika berganti-ganti pilihan. Sementara itu menjadi merugikan bagi produk lama (leader brand) yang ditinggalkan karena keinginan untuk berganti-ganti produk atau brand akan mengurangi kesempatan penggunaan produk. Kerugian tidak hanya sebatas ini, tetapi bisa menjadi lebih besar jika proses berganti-ganti alternatif bisa memberikan sensasi positif bagi konsumen karena ia akan dengan mudah beralih produk (brand switching). 


\section{Harga}

Swastha (2003) menyatakan harga suatu merek yang terlalu mahal dengan karakteristik yang ditawarkan sama dengan merek pesaing dapat menyebabkan konsumen berpindah merek, konsumen akan loyal pada merek yang berkualitas dengan harga yang wajar. Sedangkan menurut Tjiptono (2008) "Harga adalah sejumlah uang yang mengandung kegunaan tertentu yang diperlukan untuk mendapatkan suatu barang atau jasa.

\section{Tingkat Keterlibatan}

Keterlibatan konsumen merupakan suatu hal yang tidak akan lepas saat konsumen melakukan serangkaian proses pembelian. Selain pada saat tingkat keterlibatan konsumen yang tinggi, pada saat tingkat keterlibatan konsumen yang rendahpun konsumen tetap dapat membuat keputusan pembelian. Morissan (2010) mengatakan "Pada umumnya konsumen memiliki tingkat keterlibatan yang rendah dalam penelitian sebagian besar produk yang murah. Konsumen tidak secara luas mencari informasi tentang merek, mengevaluasi karakteristik merek dan memutuskan apa yang akan dibeli”. Sedangkan menurut Pranita dan Irawanto (2011) "Para responden cukup menggunakan ketelibatannya di dalam memilih kartu seluler yang digunakannya. Keterlibatan dapat berkisar dari tingkat rendah (sedikit atau tidak ada relevansi) ke moderat (ada relevansi yang dirasakan) hingga ke tingkat tinggi (relevansinya sangat dirasakan). Faktor terpenting yang mempengaruhi tingkat keterlibatan konsumen menurut Mowen dan Minor (2002) adalah sebagai berikut:

1. Jenis produk yang menjadi pertimbangan.

2. Karakteristik komunikasi yang diterima konsumen.

3. Karakteristik situasi dimana konsumen beroperasi.

4. Kepribadian konsumen.

5. Pengalaman sebelumnya dengan barang atau jasa yang telah dipakai.

\section{Kepuasan}

Dalam suatu pembelian, konsumen tidak hanya berhenti sampai proses konsumsi, konsumen akan mengevaluasi produk atau jasa yang telah dikonsumsinya tersebut. Konsumen akan memiliki perasaan puas atau tidak puas terhadap proses konsumsinya. Pelanggan akan merasa puas apabila produk atau jasa yang mereka dapatkan sesuai dengan yang diharapkan. Sebaliknya, apabila konsumen merasakan ketidakpuasan berarti produk atau jasa yang mereka dapatkan di bawah harapannya. Seorang konsumen yang mengalami ketidakpuasan bisa jadi konsumen akan mencari alternatif lain dengan cara melakukan perpindahan merek.

\section{Hipotesis}

H1: Diduga terdapat pengaruh secara simultan variabel iklan, kebutuhan mencari variasi (variety seeking), harga, tingkat keterlibatan dan kepuasan terhadap keputusan perpindahan merek (brand switching).

H2: Diduga iklan berpengaruh secara parsial terhadap brand switching. 
H3: Diduga variety seeking berpengaruh secara parsial brand switching.

H4: Diduga harga berpengaruh secara parsial terhadap brand switching .

H5: Diduga tingkat keterlibatan berpengaruh secara parsial terhadap brand switching.

H6: Diduga kepuasan berpengaruh secara parsial terhadap brand switching.

H7:Diduga variabel iklan mempunyai pengaruh yang paling dominan terhadap keputusan perpindahan merek (brand switching).

\section{METODE PENELITIAN}

Metode penelitian yang digunakan adalah metode kuantitatif. Jenis penelitian yang digunakan adalah penelitian assosiatif (hubungan). Penelitian ini dilakukan pada konsumen Pandumedia Reload Service yang bertempat di Jalan Raya no.88 Singosari Malang. Pandumedia Reload Service adalah salah satu usaha yang bergerak di bidang penjualan pulsa elektrik all operator yang juga merupakan distributor pulsa elektrik. Teknik pengambilan sampel yang digunakan adalah teknik sampling purposive. ). Jadi sampel yang diambil ditentukan oleh peneliti dengan memberikan karakteristik sebagai pertimbangan dengan jumlah 100 orang.

\section{DEFINISI OPERASIONAL VARIABEL}

1. Iklan (adversiting) adalah setiap bentuk komunikasi non personal mengenai suatu organisasi, produk, servis, atau ide yang dibayar oleh sponsor yang diketahui. Indikatorindikator yang digunakan yaitu tawaran menarik, keunggulan produk, media iklan yang digunakan dan intensitas iklan.

2. Kebutuhan mencari variasi (variety seeking)

Kebutuhan mencari variasi (variety seeking) adalah sebuah komitmen kognitif untuk membeli merek yang berbeda karena berbagai alasan yang berbeda, keinginan baru atau timbulnya rasa bosan pada sesuatu yang telah lama dikonsumsi. Indikator dalam penelitian ini adalah rasa bosan, rasa ingin tahu dan keinginan baru.

3. Harga

Harga dapat diartikan sebagai sejumlah uang yang berguna untuk mendapatkan produk atau jasa. Indikator dari harga adalah harga yang ditawarkan, harga kartu prabayar dan perubahan harga.

4. Tingkat keterlibatan

Keterlibatan konsumen adalah pribadi yang dirasakan penting dan/ minat konsumen terhadap perolehan konsumsi dan disposisi barang, jasa atau ide. Indikator yang digunakan adalah pengetahuan tentang produk dan motivasi.

5. Kepuasan

Kepuasan pelanggan adalah perasaan senang atau kecewa seseorang yang muncul setelah membandingkan antara persepsi atau kesannya terhadap kinerja atau 
hasil suatu produk dan jasa serta kesesuaian dengan harapannya. Indikator kepuasan pada penelitian ini terdiri dari kualitas produk dan kinerja perusahaan.

6. Perpindahan merek (brand switching)

Perpindahan merek (brand switching) menurut Petter dan Olson (2003) adalah perpindahan loyalitas dari satu merek ke merek lain dalam kategori produk sejenis, untuk barbagai macam alasan tertentu. Indikator dari perpindahan merek (brand switching) adalah rasa kecewa, kesetiaan yang terbagi dan peralihan sewaktu-waktu.

\section{HASIL PENELITIAN DAN}

\section{PEMBAHASAN}

\section{Karakteristik Responden}

Berdasarkan karaketsristik responden diketahui bahwa jumlah responden terbanyak berdasarkan usia adalah 17-25 tahun yakni $42 \%$, jika didasarkan pada jenjang usia, usia tersebut merupakan usia remaja. Kemudian disusul dengan usia > 25 tahun yang berjumlah 36\%. Sedangkan jumlah terkecil adalah usia < 17 tahun yang berjumlah 22\%. Dari jenis kelamin diketahui sebanyak 32 (32\%) adalah responden berjenis kelamin laki-laki dan $68(68 \%)$ berjenis kelamin perempuan. responden yang belum menikah sebanyak 59 (59\%), sedangkan sisanya yaitu $41 \quad(41 \%)$ adalah responden yang sudah menikah.

\section{ANALISIS DATA}

\section{Analisis Deskriptif}

$$
\begin{aligned}
& \text { Analisis data deskriptif digunakan } \\
& \text { untuk mendeskripsikan jawaban kuesioner } \\
& \text { yang telah diisi } 100 \text { responden }
\end{aligned}
$$

\section{Analisis Data Inferensial}

Analisis statistik inferensial yang digunakan dalam penelitian ini adalah regresi linier berganda. Di dalam analisis regresi linier berganda terdapat beberapa langkah yaitu mengitung validitas dan reliabilitas selanjutnya menginterpretasikan hasil perhitungan regresi.

\section{HASIL DAN PEMBAHASAN}

Penelitian ini dilakukan karena semakin ketatnya persaingan bisnis di bidang usaha penyedia jasa dari telepon seluler akibat menjamurnya produk tersebut dipasaran, terutama pada kartu prabayar XL yang mengalami penurunan di tahun terakhir yaitu pada tahun 2011 ke tahun 2012. Penurunan pengguna kartu prabayar XL ini diakibatkan karena para pengguna XL telah berpindah pada produk pesaing atau berpindah merek. Untuk bertahan di tengah persaingan yang semakin ketat maka produsen harus mengidentifikasi faktorfaktor yang menyebabkan konsumen melakukan perpindahan merek untuk meminimalisir terjadinya perpindahan merek yang lebih tinggi. 
Ada beberapa faktor yang menyebabkan seseorang memutuskan untuk melakukan perpindahan merek. Faktor tersebut diantaranya adalah iklan, kebutuhan mencari variasi (variety seeking), harga, tingkat keterlibatan dan kepuasan. Hal ini sesuai dengan yang dikatakan oleh beberapa ahli berikut.

Menurut Shimp (2003) "Periklanan lebih jauh dapat digunakan untuk mempengaruhi peralihan merek (brand switching) dengan mengingatkan konsumen yang membeli suatu merek yang tersedia dan mengandung atribut-atribut yang menguntungkan". Sedangkan Kotler \& Keller (2009) mengatakan "Perilaku peralihan merek terjadi untuk mencari keragaman dan bukan karena ketidakpuasan”. Swastha mengemukakan, "Harga suatu merek yang terlalu mahal dengan karakteristik yang ditawarkan sama dengan merek pesaing dapat menyebabkan konsumen berpindah merek, konsumen akan loyal pada merek yang berkualitas dengan harga yang wajar". Dalam penelitian yang dilakukan Pranita dan Irawanto (2011) menyimpulkan bahwa para responden cukup menggunakan ketelibatannya di dalam memilih kartu seluler yang digunakannya. Sedangkan penelitian yang dilakukan Emelia (2010) Koencoro dan Marlien (2009) menyimpulkan bahwa apabila kepuasan semakin tinggi maka brand switching semakin menurun.

Penelitian ini bertujuan untuk mengetahui apakah variabel iklan $\left(X_{1}\right)$, variety seeking $\left(\mathrm{X}_{2}\right)$, harga $\left(\mathrm{X}_{3}\right)$, tingkat keterlibatan $\left(\mathrm{X}_{4}\right)$ dan kepuasan $\left(\mathrm{X}_{5}\right)$ berpengaruh secara parsial dan simultan terhadap keputusan perpindahan merek (brand switching) (Y), dan seberapa besar pengaruh iklan $\left(\mathrm{X}_{1}\right)$, variety seeking $\left(\mathrm{X}_{2}\right)$, harga $\left(X_{3}\right)$, tingkat keterlibatan $\left(X_{4}\right)$ dan kepuasan $\left(\mathrm{X}_{5}\right)$ terhadap keputusan perpindahan merek (brand switching) (Y). Selain itu penelitian ini juga untuk mengetahui variabel manakah antara iklan $\left(\mathrm{X}_{1}\right)$, variety seeking $\left(\mathrm{X}_{2}\right)$, harga $\left(\mathrm{X}_{3}\right)$, tingkat keterlibatan $\left(\mathrm{X}_{4}\right)$ dan kepuasan $\left(\mathrm{X}_{5}\right)$ yang paling dominan mempengaruhi keputusan perpindahan merek (brand switching) (Y).

Berdasarkan hasil pengolahan data maka dapat diketahui bahwa:

\section{Pengaruh iklan $\left(\mathbf{X}_{1}\right)$, variety seeking} $\left(\mathbf{X}_{2}\right)$, harga $\left(\mathbf{X}_{3}\right)$, tingkat keterlibatan $\left(\mathbf{X}_{4}\right)$ dan kepuasan $\left(\mathbf{X}_{5}\right)$ secara simultan terhadap brand switching (Y) pada kartu prabayar XL.

Variabel independen (iklan, variety seeking, harga, tingkat keterlibatan dan kepuasan) memiliki pengaruh yang signifikan secara simultan terhadap variabel dependen karena telah diketahui bahwa nilai $\mathrm{f}_{\text {hitung }}(11.615)>\mathrm{f}_{\text {tabel }}$ (2.311) dengan nilai signifikan $0.000<0.05$ maka $\mathrm{H}_{1}$ diterima. Hasil penelitian ini mendukung penelitian sebelumnya yang dilakukan Haryono dan Soesanto (2012) bahwa ketidakpuasan konsumen, kebutuhan mencari variasi, 
harga dan iklan produk pesaing secara bersama-sama berpengaruh positif dan signifikansi terhadap variabel keputusan perpindahan merek.

2. Pengaruh iklan $\left(X_{1}\right)$, variety seeking $\left(X_{2}\right)$, harga $\left(X_{3}\right)$, tingkat keterlibatan $\left(\mathrm{X}_{4}\right)$, dan kepuasan $\left(\mathrm{X}_{5}\right)$ secara parsial terhadap brand switching (Y) pada kartu prabayar XI.

\section{a. Pengaruh iklan terhadap brand} switching pada kartu prabayar XL

Berdasarkan hasil penelitian diketahui variabel iklan mempunyai $\mathrm{t}_{\text {hitung }}(-1.310)<\mathrm{t}_{\text {tabel }}$ (1.985) dan nilai signifikan 0.193 $>0.05$, maka dapat disimpulkan bahwa variabel iklan tidak berpengaruh signifikan terhadap perpindahan merek (brand switching) pada kartu prabayar XL.

Dalam penelitian ini iklan tidak berpengaruh secara linier terhadap perpindahan merek (brand switching) pada kartu prabayar XL. Ini dibuktikan dengan sebanyak $57 \%$ responden berpindah merek karena lebih sering melihat iklan kartu prabayar yang digunakan saat ini.

$$
\text { Hasil penelitian ini }
$$
sependapat dengan penelitian yang dilakukan oleh Bahtiyar (2013) bahwa iklan tidak berpengaruh terhadap perpindahan merek dan tidak mendukung hasil penelitian sebelumnya yang dilakukan oleh Radamuri dkk, (2013), Haryono dan Soesanto (2012) bahwa faktor iklan berpengaruh terhadap perilaku brand switching. Hasil penelitian ini juga tidak sejalan dalam teori yang dikatakan Shimp (2003) bahwa periklanan lebih jauh dapat digunakan untuk mempengaruhi peralihan merek (brand switching).

b. Pengaruh variety seeking terhadap brand switching pada kartu prabayar XI

Berdasarkan hasil penelitian diketahui variabel variety seeking mempunyai $\mathrm{t}_{\text {hitung }}$ $(5.308)>t_{\text {tabel }}(1.985)$ dan nilai signifikan $0.000<0.05$, maka dapat disimpulkan bahwa variabel variety seeking berpengaruh signifikan terhadap perpindahan merek (brand switching).

Dalam penelitian ini variety seeking berpengaruh signifikan terhadap perpindahan merek pada kartu prabayar XL. Responden melakukan keputusan perpindahan merek karena responden merasa bosan dengan produk yang lama, memiliki rasa ingin tahu pada produk baru dan mempunyai kesenangan mencoba hal baru. Hal ini sesuai dengan 
Dalam penelitian ini tingkat keterlibatanberpengaruh secara signifikan terhadap perpindahan merek pada kartu prabayar XL. Hal ini sependapat dengan penelitian yang dilakukan Pranita dan Irawanto (2011) bahwa "Para responden cukup menggunakan keterlibatannya di dalam memilih kartu seluler yang digunakannya". Hasil penelitian ini juga sesuai dengan teori yang dikatakan Morissan (2010) bahwa pada umumnya konsumen memiliki tingkat keterlibatan yang rendah dalam pembelian sebagian besar produk yang murah.

\section{e. Pengaruh kepuasan terhadap brand switching pada kartu prabayar XL}

Berdasarkan hasil penelitian diketahui variabel kepuasan mempunyai $\mathrm{t}_{\text {hitung }}(1.842)<$ $\mathrm{t}_{\text {tabel }}(1.985)$ dan nilai signifikan $0.069>0.05$, maka dapat disimpulkan bahwa variabel kepuasan tidak berpengaruh signifikan terhadap perpindahan merek (brand switching). Dalam penelitian ini sebanyak $18 \%$ dan $8 \%$ responden mengatakan bahwa operator XL tidak cepat dalam menangani keluhan. Namun meskipun begitu kepuasan tidak berpengaruh signifikan terhadap perpindahan merek pada kartu prabayar XL. Hasil penelitian ini mendukung hasil penelitian sebelumnya dari Emelia (2010), Koencoro dan Marlien (2010) yang menyimpulkan bahwa apabila kepuasan konsumen semakin tinggi, maka akan mengakibatkan konsumen melakukan perilaku perpindahan merek semakin rendah, sedangkan untuk kepuasan yang didapat semakin rendah maka akan mengakibatkan konsumen untuk melakukan perilaku perpindahan merek semakin tinggi. Hal ini juga sesuai dengan teori yang dikatakan Kotler \& Keller (2009) bahwa perilaku peralihan merek terjadi untuk mencari keragaman bukan karena ketidakpuasan.

3. Pengaruh iklan $\left(\mathrm{X}_{1}\right)$, variety seeking $\left(\mathrm{X}_{2}\right)$, harga $\left(\mathrm{X}_{3}\right)$, tingkat keterlibatan $\left(\mathrm{X}_{4}\right)$, dan kepuasan $\left(\mathrm{X}_{5}\right)$ yang paling dominan terhadap keputusan perpindahan merek (brand switching). Untuk mengetahui variabel yang mempunyai pengaruh paling dominan dapat dilihat pada tabel 4.10 kolom koefisien B. Dari tabel tersebut dapat dilihat bahwa nilai tertinggi dari koefisien B sebesar 0.379. Jadi kesimpulannya nilai koefisien yang paling dominan adalah variabel tingkat keterlibatan sebesar 0.379 .

\section{KESIMPULAN DAN SARAN}

\section{Kesimpulan}

1. Berdasarkan hasil analisa menunjukkan bahwa kelima variabel independen (iklan, variety seeking, harga, tingkat keterlibatan dan kepuasan) secara simultan berpengaruh terhadap keputusan perpindahan merek pada kartu prabayar XL. Ini dibuktikan dengan nilai $\mathrm{f}_{\text {hitung }}(11.615)>\mathrm{f}_{\text {tabel }}$ (2.311) dengan nilai signifikan $<0.05$ yaitu 
0.000. Hal ini menunjukkan bahwa hipotesis pertama yang menduga terdapat pengaruh secara simultan antara variabel iklan $\left(\mathrm{X}_{1}\right)$, variety seeking $\left(\mathrm{X}_{2}\right)$, harga $\left(\mathrm{X}_{3}\right)$, tingkat keterlibatan $\left(\mathrm{X}_{4}\right)$ dan kepuasan $\left(\mathrm{X}_{5}\right)$ terhadap keputusan perpindahan merek (brand switching) diterima.

2. Berdasarkan hasil analisa menunjukkan secara parsial variabel iklan $\left(\mathrm{X}_{1}\right)$, harga $\left(\mathrm{X}_{3}\right)$ dan kepuasan $\left(\mathrm{X}_{5}\right)$ tidak berpengaruh signifikan terhadap perpindahan merek (brand switching). Sedangkan untuk variabel variety seeking $\left(\mathrm{X}_{2}\right)$ dan tingkat keterlibatan $\left(\mathrm{X}_{4}\right)$ berpengaruh signifikan secara parsial terhadap perpindahan merek (brand switching). Sehingga hipotesis kedua yang menduga bahwa 92 berpengaruh secara parsial terhadap brand switching, hipotesis keempat yang menduga bahwa harga berpengaruh secara parsial terhadap brand switching dan hipotesis keenam yang menduga bahwa kepuasan berpengaruh secara parsial terhadap brand switching ditolak. Sedangkan hipotesis ketiga yang menduga bahwa variety seeking berpengaruh secara parsial terhadap brand switchin danhipotesis kelima yang menduga bahwa tingkat keterlibatan berpengaruh secara parsial terhadap brand switching diterima.
3. Besar pengaruh variabel iklan $\left(\mathrm{X}_{1}\right)$, variety seeking $\left(\mathrm{X}_{2}\right)$, harga $\left(\mathrm{X}_{3}\right)$, tingkat keterlibatan $\left(\mathrm{X}_{4}\right)$ dan kepuasan $\left(\mathrm{X}_{5}\right)$ secara simultan adalah 11.615 dengan nilai signifikan 0.000 , sedangkan secara parsial variabel iklan $\left(X_{1}\right)$ memiliki pengaruh sebesar -1.310 , variety seeking $\left(\mathrm{X}_{2}\right)$ 5.308, harga $\left(\mathrm{X}_{3}\right) \quad-0.111$, tingkat keterlibatan $\left(\mathrm{X}_{4}\right) 3.130$ dan kepuasan $\left(\mathrm{X}_{5}\right)$ sebesar 1.842 .

4. Nilai koefiien yang paling dominan adalah variabel tingkat keterlibatan $\left(\mathrm{X}_{4}\right) \quad$ sebesar 0.379 , sehingga hipotesis ketujuh yang menduga bahwa variabel iklan memiliki pengaruh paling dominan ditolak.

\section{Saran}

1. Berdasarkan kesimpulan di atas didapat variabel kebutuhan mencari variasi (variety seeking) dan tingkat keterlibatan berpengaruh signifikan terhadap perilaku perpindahan merek (brand switching). Untuk itu produsen hendaknya sering melakukan inovasi terhadap produknya agar konsumen tidak merasa bosan dengan produk tersebut.

2. Bagi peneliti selanjutnya diharapkan menambahkan faktor-faktor lain selain kelima variabel yang telah digunakan dalam penelitian ini terhadap perpindahan merek (brand switching) serta objek dan tempat yang berbeda.

\section{DAFTAR PUSTAKA}


Arikunto, Suharsimi. 2003. Prosedur Penelitian Suatu Pendekatan Praktek. Jakarta: Rineka Cipta.

Aritonang, Lerbin. 2007. Riset Pemasaran. Bogor: Ghalia Indonesia.

Ghozali, Imam. 2001. Analisis Multivariate Dengan SPSS. Semarang: BP UNDIP

Ghozali, Imam. 2006. Analisis Multivariate Lanjutan Dengan SPSS. Edisi 1.Semarang: BP UNDIP

Kotler Philip dan Lane Keller, Kevin. 2009. Manajemen pemasaran jilid 1. Jakarta: Erlangga.

Kotler Philip dan Lane Keller, Kevin. 2009. Manajemen pemasaran jilid 2. Jakarta: Erlangga.

Morissan, M.A. 2010. Periklanan Komunikasi Pemasaran Terpadu. Jakarta: Kencana.

Mowen, Jhon. C., dan Minor, Michael., 2002, Perilaku Konsumen. Jakarta: Erlangga.

Nicolino, Patricia F. MBA. 2004. Brand Management. Jakarta: Prenada Media.

Peter, J. Paul dan Jerry C. Olson. 2003. Perilaku Konsumen dan Strategi Pemasaran jilid 1. Jakarta: Erlangga.

Peter, J. Paul dan Jerry C. Olson. 2003. Perilaku Konsumen dan Strategi Pemasaran jilid 2. Jakarta: Erlangga.

Rangkuti, Freddy. 2006. The Power of Brands. Jakarta: PT Gramedia Pustaka Utama.

Shimp, Terence. A. 2003. Periklanan Promosi: Aspek Tambahan Komunikasi Pemasaran Terpadu. Jakarta : Erlangga. Schiffman, Leon G. dan Leslie Lazar Kanuk. 2007. Perilaku Konsumen. Jakarta: Indeks.
Stanton.J, William. 2000. Prinsip Pemasaran. Jakarta: Erlangga.

Sugiyono. 2006. Metode Penelitian Bisnis. Bandung: Alfabeta.

Sudrajat. 2001. Dasar-Dasar Penelitian Ilmiah. Bandung: CV. Pustaka Setia

Swastha, Basu. 2003. Pergeseran Paradigma dalam Pemasaran: Tinjauan Manajerial dan Perilaku Konsumen. Jakarta: Erlangga.

Tjiptono, Fandy. 2008. Strategi Pemasaran. Yogyakarta:CV. Andi Offset.

Jathu Andina, Pranita dan W.Irawanto, Dodi. 2011. Pengaruh Kinerja Produk, Tingkat Kepuasan dan Tingkat Keterlibatan pada Perilaku Perpindahan Merek. Malang: Jurnal Universitas Brawijaya.

Koencoro, Bambang dan Marlien. 2009. Analisis Perilaku Brand Switching Pembelian Notebokk di Kota Semarang. Jurnal Fakultas Ekonomi Universitas Stikubank.

Tri haryono, Cahyo dan Soesanto, Drs. harry, MMR. 2012. Analisis pengaruh ketidakpuasan konsumen, kebutuhan mencari variasi produk, harga produk dan iklan produk pesaing ter 96 perpindahan merek. Jurnal.

Y.D. Radamuri, Grace,. Farida, Naili \& Shinta Dewi, Reni. 2013. Pengaruh citra merek, Word of mouth dan Iklan terhadap Keputusan Perpindahan Merek. Diponegoro: Jurnal fakultas ilmu sosial dan ilmu politik, universitas Diponegoro. 
http://m.merdeka.com/teknologi/indonesia-

negara-denganpertumbuhanbroadband-

tertinggi.html

http://id.wikipedia.org/wiki/Telekomunikasi_s eluler_di_Indonesia

Indosat public Expose tahun 2012

www.xl.co.id

Laporan Tahunan XL Axiata 2012 